Article

\title{
Bio-Crude Production through Aqueous Phase Recycling of Hydrothermal Liquefaction of Sewage Sludge
}

\author{
Ayaz A. Shah ${ }^{1,2}$, Saqib S. Toor ${ }^{1, *}$, Tahir H. Seehar ${ }^{1,2}$, Rasmus S. Nielsen ${ }^{3}$, Asbjørn H. Nielsen ${ }^{4}$, \\ Thomas H. Pedersen ${ }^{1}$ (D) and Lasse A. Rosendahl ${ }^{1}$ (D) \\ 1 Department of Energy Technology, Aalborg University, Pontoppidanstræde 111, 9220 Aalborg, Denmark; \\ ash@et.aau.dk (A.A.S.); ths@et.aau.dk (T.H.S.); thp@et.aau.dk (T.H.P.); lar@et.aau.dk (L.A.R.) \\ 2 Department of Energy \& Environment Engineering, Dawood University of Engineering \& Technology; New \\ M. A. Jinnah Rd, Jamshed Quarters Muslimabad, Karachi, Sindh 74800, Pakistan \\ 3 Department of Chemistry and Bioscience, Aalborg University, Fredrik Bajers Vej 7H, 9220 Aalborg, Denmark; \\ rsn@bio.aau.dk \\ 4 Department of Civil Engineering, Aalborg University, Thomas Manns Vej 23, 9220 Aalborg, Denmark; \\ ahn@civil.aau.dk \\ * Correspondence: sst@et.aau.dk; Tel.: +45-30460544
}

Received: 25 November 2019; Accepted: 17 January 2020; Published: 19 January 2020

\begin{abstract}
Hydrothermal liquefaction (HTL) is a promising technology for the production of bio-crude. However, some unresolved issues still exist within HTL, which need to be resolved before its promotion on a commercial scale. The management of the aqueous phase is one of the leading challenges related to HTL. In this study, the sewage sludge has been liquefied at $350{ }^{\circ} \mathrm{C}$ with and without catalyst $\left(\mathrm{K}_{2} \mathrm{CO}_{3}\right)$. Subsequently, aqueous phase recycling was applied to investigate the effect of recycling on bio-crude properties. Obtained results showed that the energy recovery in the form of bio-crude increased by $50 \%$ via aqueous phase recirculation, whereas nitrogen content in the bio-crude was approximately doubled after eight rounds of recycling. GCMS characterization of the aqueous phase indicated acetic acid as a major water-soluble compound, which employed as a catalyst $(0.56 \mathrm{M})$, and resulted in a negligible increase in bio-crude yield. ICP-AES highlighted that the majority of the inorganics were transferred to the solid phase, while the higher accumulation of potassium and sodium was found in the aqueous phase via successive rounds of recycling.
\end{abstract}

Keywords: aqueous phase recycling; sewage sludge; hydrothermal liquefaction; bio-crude

\section{Introduction}

Increasing world population intensifies the global energy demand. The imbalance in supply and demand emerges a need for the exploration of new pathways for the production of energy [1]. It has been established that renewable sources of energy have great importance for sustainable development. Moreover, the increasing consciousness about environmental threats such as global warming has directed the world towards the usage of renewable sources [2].

Biomass is a renewable energy source that is abundantly available as a wide range of materials, which includes agricultural waste, organic wastes such as food, sewage sludge, etc. [3]. Sewage sludge (SS) is a heterogeneous material originated from the wastewater treatment. SS is comprised of a high amount of water content, carbohydrates, proteins, lipids, and other toxic and non-toxic inorganic elements [4]. Due to massive urbanization and rapid growth in population, the production of SS has become a crucial issue that obstacles urban development and creates environmental pollution [5]. In the European Union (EU), by implementing Urban Waste Water Treatment (UWWT) Directive 
91/271/EC (CEC, 1991), the total annual SS production from the EU will exceed 13 million dry tons by 2020 [6]. Over the years, landfill, incineration, and agricultural applications are mostly adopted ways for the disposal of SS, and these technologies are facing several challenges due to limited land and strict environmental regulations [7]. Therefore, it is essential to establish an alternative disposal route, involving recycling and safe disposal simultaneously. SS is enriched with volatiles, and thus, recognized as a bio-resource for the production of liquid fuels and a variety of chemicals [8]. The higher heating value (HHV) of SS varies between 12 to $20 \mathrm{MJ} / \mathrm{kg}$, which is in line with other energy-rich biomass [9].

Currently, for biomass conversion, hydrothermal liquefaction (HTL) has received much attention in the recent past due to the efficient processing of wet feedstocks. HTL works at moderate temperatures, and high pressures wherein water facilitates acid-base catalyzed reactions for the disintegration of the organic matter [10]. In HTL, from the past two decades, SS has been considered as a viable feedstock for the production of bio-crude due to its low cost and abundant accessibility [11,12]. For SS, HTL is the best choice of technology due to the high water content, and this water emerges to be a by-product of the process, which must be managed sustainably. This effluent water from the HTL process is often termed process water or aqueous phase containing water-soluble organics. From the literature based on HTL of SS, the majority of studies were published on the production of bio-crude and energy recovery [13-15]. However, few articles are available on the characterization of the aqueous phase. Maddi et al. quantitatively characterized the aqueous phase from primary, secondary, and digested SS, and obtained mostly N-heterocyclic compounds and short-chain acids [16]. Xu et al. treated SS under subcritical conditions and reported a decrease in total organic carbon (TOC) level (19 to $9 \mathrm{~g} / \mathrm{L})$ of the aqueous phase with increasing temperatures $\left(260\right.$ to $\left.350{ }^{\circ} \mathrm{C}\right)$ [17]. Some algal biomass studies have indicated that the aqueous phase contains up to $45 \%$ of carbon and almost $80 \%$ of the nitrogen and phosphorus $[18,19]$. For this reason, it becomes necessary to create ways for the recovery of the organics and nutrients from the aqueous stream before discharging into the natural environment [20].

There are mostly two ways to implement water management in an HTL process. (1) To identify appropriate technology that can extract energy in the form of organics as well as inorganics (nutrients) directly from the aqueous phase, which is then discharged into the environment. (2) To recycle the aqueous phase back into the HTL process. In recent past, many researchers have studied the utilization of the aqueous phase via different routes like gasification, which specially produces gaseous fuel or from gas to liquid hydrocarbons [21,22], direct recycling for the cultivation of algal biomass [23], and anaerobic digestion for the production of methane gas [24], as illustrated in Figure 1a. Currently, the more recent approach is the recirculation of the aqueous phase back to the HTL unit, as several studies have revealed a positive impact on yield, and energy recovery of the bio-crude. For instance, Zhu et al. performed the recycling of aqueous phase from ligno-cellulosic biomass and reported enhanced bio-crude yield (35 to 38.4\%) after three rounds [25]. Pedersen et al. carried out recycling of aqueous phase from co-liquefaction of wood and glycerol in the continuous plant, but unfortunately, the authors could not observe a clear trend in bio-crude yield due to complex separation process, although higher amount of organic carbon and ash were detected in the aqueous phase at each recycle [26]. Ramos-Tercero et al. [27], reported an increase in bio-crude yield from 14 to $42 \%$ after seven recycles from micro-algae, whereas HHV of bio-crude was decreased via successive recycles. Biller et al. [28] carried out recycling experiments with and without catalyst $\left(\mathrm{K}_{2} \mathrm{CO}_{3}\right)$ and noticed a higher rate of increase in bio-crude yield and energy recovery in catalytic bio-crude than the non-catalytic runs from dry distillates grains with solubles (DDGS). Daniel et al. [29] also reported the higher bio-crude yield with a decrease in solids with HHVs (33-35 MJ/kg) from blackcurrant pomace. 


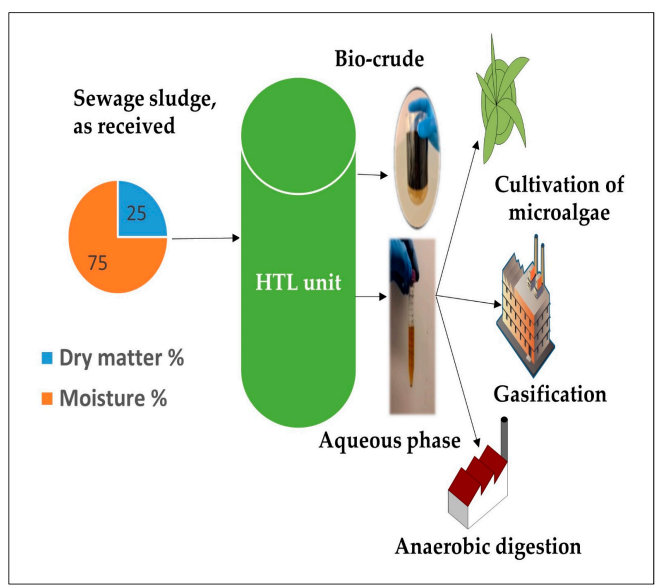

(a)

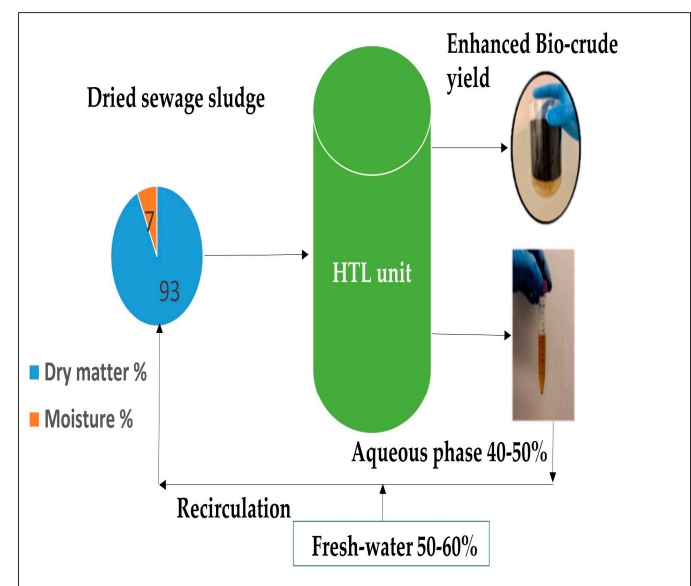

(b)

Figure 1. Optimization of the aqueous phase via (a) different processes, (b) present study.

One aspect of recycling the aqueous phase, which has not yet been addressed in the literature, is balancing the recycled water stream with the water already present in the feedstock. If a feedstock is dry, this is not very complicated, likely being only a question of adjusting water content by adding additional water to the feed stream. In the context of continuous plants for real feedstocks such as SS, there is plenty of water already in the feedstock, typically in a range of $75-95 \%$. This makes recycling of aqueous phase in the HTL process more complicated, as water must be removed to maintain the organic loading, without losing the soluble organics. To address aqueous phase recycling for SS in a continuous process, a series of well-controlled batch experiments have been carried out. In these, dried SS has been processed at hydrothermal conditions with the recycling of soluble organics, using make-up water to maintain a constant organic loading of the process as demonstrated in Figure 1b. In summary, this study aims to obtain fundamental information about the implications of aqueous phase recycling on HTL products produced from the high nitrogen-containing feedstock. Furthermore, the fate of nutrients is also discussed in the last part of the study.

\section{Material and Methods}

\subsection{Feedstock Characterization}

A sample of bio-degassed SS in the form of dried pellets was collected from (Renseanlaeg Ost), Wastewater Treatment Plant, Aalborg East, Denmark [30]. The ash content was determined by burning the SS sample for $4 \mathrm{~h}$ at $775^{\circ} \mathrm{C}$. The moisture content (MC) was analyzed by the moisture analyzer (Kern, MLS) at $120^{\circ} \mathrm{C}$. Volatile matter (VM) was calculated through Thermogravimetric analysis (TGA) TA instrument Discovery, by heating the feedstock at $750{ }^{\circ} \mathrm{C}$ under the nitrogen atmosphere at 10 ${ }^{\circ} \mathrm{C} / \mathrm{min}$, as presented in Figure S1 (Supplementary Material). Crude Fat (CF) was measured by Soxhlet extraction by using petroleum ether as an extraction solvent. The Crude Protein (CP) was determined by multiplying the nitrogen content with the factor (6.25) [31]. Carbohydrates were estimated by using the formula: Carbohydrates $=[(\mathrm{VM}+\mathrm{FC})-(\mathrm{CP}+\mathrm{CF})][32]$, as illustrated in Table 1 . The HHV was measured by $\mathrm{C} 2000$ basic Calorimeter (IKA, Germany). Potassium carbonate and acetic acid were used as catalysts about $2.5 \%$ of the total $21 \mathrm{~g}$ of the slurry. The elemental composition was analyzed by the elemental analyzer (Perkin Elmer, 2400 Series II CHNS/O), operated on CHN mode. 
Table 1. Proximate and ultimate analysis (wt.\%) of SS.

\begin{tabular}{ccccccc}
\hline $\mathbf{M C}^{\mathbf{a}}$ & $\mathbf{V M}$ & $\mathbf{F C}^{\mathbf{c}}$ & Ash & Crude Protein $^{\mathbf{b}}$ & Crude Fat $^{\mathbf{b}}$ & Carbohydrates $^{\mathbf{b}}$ \\
\hline 7.54 & 54.44 & 11.54 & 34.02 & 43.21 & 4.89 & 51.89 \\
$\mathbf{C}^{\mathbf{b}}$ & $\mathbf{H}^{\mathbf{b}}$ & $\mathbf{N}^{\mathbf{b}}$ & $\mathbf{O}^{\mathbf{b}, \mathbf{d}}$ & $\mathbf{H} / \mathbf{C}$ & $\mathbf{O} / \mathbf{C}$ & $\mathbf{H H V ~ ( M J / k g )}{ }^{\mathbf{b}}$ \\
50.17 & 7.11 & 6.90 & 35.81 & 1.70 & 0.54 & 21.27 \\
\hline \multicolumn{7}{c}{}
\end{tabular}

Inductively Coupled Plasma Atomic Emission Spectroscopy (ICP-AES) technique was used for the detection of inorganic elements. Prior to analysis, the SS sample was digested in a microwave-assisted acid digestion system, as per the EPA method 3051A (US. EPA., 2007), by adopting a similar procedure as mentioned by Conti et al. [33]. Table 2 shows that the sum of total detected inorganic elements $(92,279.02 \mathrm{mg} / \mathrm{kg})$, makes around approximately $9.22 \%$ of the total ash $34 \%$ in the feedstock. This implies that the remaining inorganic part could be occupied by oxygenated anions in the form of oxides, sulfates, phosphates, and carbonates, or some other inorganic elements, such as $\mathrm{Zn}, \mathrm{Cr}, \mathrm{Cd}, \mathrm{Pb}$, etc., which were not reported in the present study. Among all inorganic elements, phosphorus and calcium covered almost $60 \%$ of the mass, whereas sodium showed the least concentration of $0.20 \%$. The relative concentration of an individual element was estimated as the concentration of each element divided by the sum of the overall concentrations of all detected elements.

Table 2. Concentration of inorganic elements in SS.

\begin{tabular}{ccc}
\hline Inorganic Elements & Concentration $\mathbf{( m g} / \mathbf{k g})$ & Relative Concentration (wt.\%) \\
\hline $\mathrm{Al}$ & $5515.77 \pm 255.25$ & 5.98 \\
$\mathrm{Ca}$ & $27,514.97 \pm 788.17$ & 29.82 \\
$\mathrm{Fe}$ & $13,239.89 \pm 788.04$ & 14.35 \\
$\mathrm{~K}$ & $2691.63 \pm 129.44$ & 2.92 \\
$\mathrm{Mg}$ & $6681.27 \pm 485.84$ & 7.24 \\
$\mathrm{Na}$ & $182.80 \pm 34.14$ & 0.20 \\
$\mathrm{P}$ & $26,244.71 \pm 889.01$ & 28.44 \\
$\mathrm{~S}$ & $8873.56 \pm 227.96$ & 9.62 \\
$\mathrm{Si}$ & $1334.43 \pm 105.32$ & 1.45 \\
\hline Total & $92,279.02$ & 100.00 \\
\hline
\end{tabular}

\subsection{Experimental Procedure}

The hydrothermal liquefaction experiments were performed in a stainless steel batch reactor of 41 $\mathrm{mL}$. A dried mass $5.60 \mathrm{~g}$ of SS was mixed with $15.40 \mathrm{~mL}$ of water in such a way that the total dry matter in the slurry was adjusted to $25 \%$. The Potassium carbonate and acetic acid were used as catalysts $(2.5 \%$ of the total slurry) for catalytic runs. The reactors were sealed and pre-pressurized with nitrogen gas at 15 bar. The reactors were submerged into a preheated sand bath at temperatures of $350^{\circ} \mathrm{C}$ and $400{ }^{\circ} \mathrm{C}$ with a residence time of $15 \mathrm{~min}$. After the reaction time, the reactors were cooled down by putting the reactors in the water container for $30 \mathrm{~min}$. Finally, the products were separated and collected. Subsequently, eight recycling experiments were carried out at $350{ }^{\circ} \mathrm{C}$ by recycling 5 to $8 \mathrm{~mL}$ of aqueous phase back to the reactor, while the remaining amount of volume was adjusted by demineralized fresh-water. The variable dilution ratio of water to aqueous phase was due to inconsistent production of the aqueous phase in each run, and to adjust the constant dry matter content $(25 \%)$ in the slurry, as given in Table 3. 
Table 3. Amount of aqueous phase and water added in the SS at each cycle.

\begin{tabular}{cccc}
\hline Cycles & Freshwater $(\mathbf{m L})$ & Aqueous Phase $(\mathbf{m L})$ & $\begin{array}{c}\text { Dilution Factor } \\
\text { (Fresh-Water/Aqueous Phase) }\end{array}$ \\
\hline C0 & 15.40 & - & - \\
C1 & 7.90 & 7.50 & 1.05 \\
C2 & 8.40 & 7.00 & 1.20 \\
C3 & 8.40 & 7.00 & 1.20 \\
C4 & 8.40 & 7.00 & 1.20 \\
C5 & 8.10 & 7.30 & 1.11 \\
C6 & 9.90 & 5.50 & 1.80 \\
C7 & 9.40 & 6.00 & 1.57 \\
C8 & 9.40 & 6.00 & 1.57 \\
\hline
\end{tabular}

All experiments were performed in duplicates except the runs $C 6, C 7$, and $C 8$, which were conducted only once due to less amount of aqueous phase. The gas was vented off by turning on the valves of the reactor. To get the mixture of bio-crude and solid residue, the reactor was rinsed with acetone. Vacuum filtration was carried out to separate the solid residue by using filter paper (VWR-particle size 5-13 $\mu \mathrm{m}$ ). The solids were dried in the oven for $24 \mathrm{~h}$ at $105^{\circ} \mathrm{C}$, then measured to report the solid yield. The left-over mixture of bio-crude and acetone was subjected to rotary evaporation at $\left(60^{\circ} \mathrm{C}, 56 \mathrm{KPa}\right)$. In the last Diethyl Ether (DEE, Sigma Aldrich, ACS reagent, anhydrous, $>99.0 \%$ ) was used to obtain the bio-crude phase and DEE phase, from which DEE was evaporated at $\left(40^{\circ} \mathrm{C}, 99 \mathrm{KPa}\right)$ and remaining bio-crude was measured. The overall methodology of the HTL process is given in Figure 2.

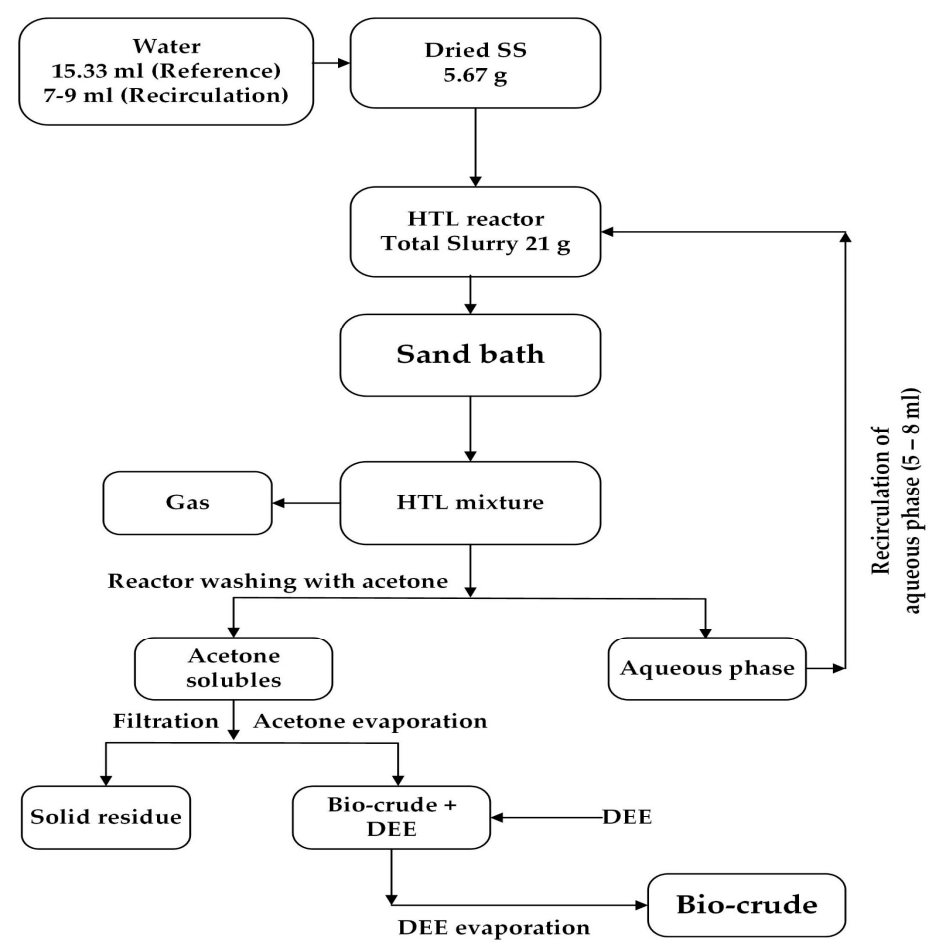

Figure 2. Schematic diagram of the HTL process with the recycling of the aqueous phase.

\subsection{Analysis of the Products}

The elemental composition of bio-crude and solid residue was analyzed by (Perkin Elmer. 2400 Series II CHNS/O) operated in CHN mode. The volatility curves of the bio-crude were obtained by heating the bio-crude at $800{ }^{\circ} \mathrm{C}$ under nitrogen atmosphere TGA (TA instrument Discovery). The composition of bio-crude and the aqueous phase was analyzed by Gas Chromatograph (Thermo 
Scientific, Trace 1300) fixed with a Mass Spectrometer (ISQ-QD). The GC oven, fixed with a capillary column (HP-5MS, Agilent Technologies, I.D.: $0.25 \mathrm{~mm}$, length: $30 \mathrm{~m}$, film thickness: $0.25 \mathrm{~mm}$ ), was set to $300{ }^{\circ} \mathrm{C}$ at the rate of $\left(10 \mathrm{~K} \mathrm{~min}^{-1}\right)$. The samples were mixed with DEE and filtered $(0.45 \mu \mathrm{m})$ prior to injection. For the aqueous phase, the water was evaporated at $80^{\circ} \mathrm{C}$ for $24 \mathrm{~h}$; then, dichloromethane was employed as a solvent to dissolve dried organic contents. A derivatization method was used according to Pedersen et al. [34].

The concentrations of the total nitrogen (TN) and total organic carbon (TOC) in the aqueous phase were analyzed by using reagent vials (LCK: 138, 386, respectively) and a spectrophotometer unit (Hach and Lange, DE3900). The $\mathrm{pH}$ of the aqueous phase was measured with a WTW $\mathrm{pH}$ meter 3210. The HHV of the bio-crude was estimated by using the Channiwala and Parikh correlation [9].

The concentration of acetic was analyzed by High-pressure liquid chromatography (HPLC) with a column (I.D.: $7.8 \mathrm{~mm}$, length: $30 \mathrm{~cm}$ ), at a temperature of $30^{\circ} \mathrm{C}$, with Refractive index detector (RID, Waters 2414). The samples were filtered with $0.12 \mu \mathrm{m}$ filter paper, prior to injection in the column. The results were interpreted by preparing the standard calibration curve at different concentrations of acetic acid. The concentration of inorganic elements in the bio-crude, solids, and the aqueous phase was determined by ICP-AES.

The product yield on dry ash-free (daf) basis, energy recovery in bio-crude (ER), and carbon recovery (CR) were estimated by using the following equations. Here, $\mathrm{Wp}$ and $\mathrm{Wf}$, represent the weights of the products and feedstock, whereas $\mathrm{Cp}$ and $\mathrm{Cf}$ indicate carbon $\%$ in the products and feedstock. Cap denotes the recirculated carbon\% from the aqueous phase.

$$
\begin{gathered}
\text { Product yield }(\%) \text { in bio }- \text { crude and solid }=\frac{\mathrm{Wp}(\text { daf })}{\mathrm{Wf}(\text { daf })} \times 100 \\
\text { ER }(\%) \text { in bio }- \text { crude }=\frac{\mathrm{HHV} \text { of bio }- \text { crude }}{\mathrm{HHV} \text { of feedstock }} \times \text { bio }- \text { crude yield } \\
\mathrm{CR}(\%) \text { in bio }- \text { crude and solids }=\frac{\mathrm{Cp} \mathrm{Wp}}{\mathrm{Cf} \mathrm{Wf}} \times 100 \\
\mathrm{CR}(\%) \text { in aqueuous phase }=\frac{\mathrm{TOC}(\mathrm{g} / \mathrm{l}) \times \text { aqueous phase produced in }(\mathrm{l})}{\mathrm{Cf} \mathrm{Wf}} \times 100 \\
\mathrm{CR}(\%) \text { in products with recirculation }=\frac{\mathrm{Cp} \mathrm{Wp}}{\mathrm{Cf} \mathrm{Wf}+\mathrm{Cap}} \times 100 \\
\mathrm{HHV}(\mathrm{MJ} / \mathrm{kg})=(0.3419) \mathrm{C}+(1.11783) \mathrm{H}+(0.1005) \mathrm{O}-(0.1034) \mathrm{N}
\end{gathered}
$$

\section{Results and Discussion}

\subsection{Effect of Temperature and Catalyst on Products Yield}

Initially, three experiments were performed without recycling of the aqueous phase, two at subcritical conditions with (Cat- $\mathrm{K}_{2} \mathrm{CO}_{3}$ ), and without catalyst (350-None). To investigate the effect of the temperature at a supercritical state, one experiment was conducted in duplicate without catalyst (400-None), as given in Figure 3. In terms of temperature perspective, at both conditions, almost the same yields ( $25.30 \%$ at $350-N o n e$, and $23.90 \%$ at $400-N o n e)$ were obtained with a minor difference of $1.4 \%$ that can be ignored under the experimental protocols. Nevertheless, the slightly lower bio-crude yield with small error bars at 400-None might be due to the conversion of bio-crude fractions to aqueous or gas phase via cracking reactions above the critical point $\left(374{ }^{\circ} \mathrm{C}\right)$. The Cat- $\mathrm{K}_{2} \mathrm{CO}_{3}$ bio-crude showed the highest bio-crude yield ( $28.5 \%$ ). It is primarily due to the hydrolysis of carbohydrate components, which accounted for $52 \%$. Alkali carbonates assist in the hydrolysis and cleavage of glycosidic bonds and reduce the formation of char [35]. 


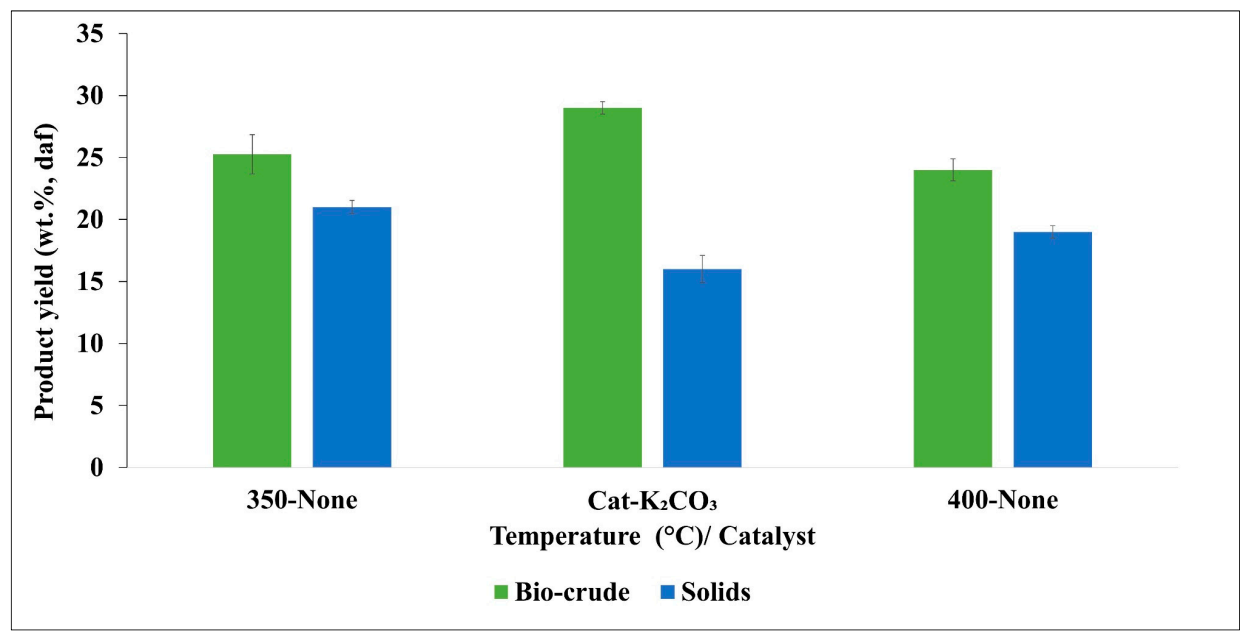

Figure 3. Product yield at sub and supercritical conditions.

In the overall scenario, no significant improvement in bio-crude yield was observed by the addition of catalyst due to the substantial amount of proteins (43\%) present in the SS. Previously, Yulin et al. highlighted that the alkali catalyst is not favorable for the conversion of high protein-containing feedstocks [20]. In our case, an approximately 3\% increase in bio-crude yield is attributed to the higher carbohydrate fractions rather than to the proteins in the SS, as mentioned in Table 1. Previously Yokoyama et al. has already reported the enhanced bio-crude yield from SS containing $57 \%$ of carbohydrates by using $2.5 \%$ of sodium carbonate as a catalyst [36]. Therefore, we can conclude that the role of the alkali catalyst is strongly dependent upon the biochemical composition of the feedstock. At both temperatures, almost similar carbon and hydrogen contents were found, whereas Catalytic- $\mathrm{K}_{2} \mathrm{CO}_{3}$ bio-crude showed maximum energy recovery $(44.09 \%)$ with $\mathrm{HHV}$ of $(36.45 \mathrm{MJ} / \mathrm{kg})$ as listed in Table 4.

Table 4. The elemental analysis of the bio-crude at sub and supercritical conditions.

\begin{tabular}{|c|c|c|c|c|c|c|c|c|}
\hline \multirow[t]{2}{*}{ Samples } & \multicolumn{4}{|c|}{ Elemental Analysis (wt. \%) } & \multirow[t]{2}{*}{$\operatorname{HHV}(\mathrm{MJ} / \mathrm{kg})^{a}$} & \multirow[t]{2}{*}{$\mathrm{H} / \mathrm{C}$} & \multirow[t]{2}{*}{$\mathrm{O} / \mathrm{C}$} & \multirow[t]{2}{*}{ ER $(\%)$} \\
\hline & $\mathrm{C}$ & $\mathrm{H}$ & $\mathrm{N}$ & $\mathrm{O}^{\mathrm{b}}$ & & & & \\
\hline SS & 50.17 & 7.11 & 6.91 & 35.81 & 21.27 & 1.70 & 0.54 & - \\
\hline 350-None & 73.85 & 10.04 & 4.67 & 11.44 & 35.22 & 1.63 & 0.12 & 39.57 \\
\hline 400-None & 74.12 & 10.12 & 4.42 & 11.34 & 35.42 & 1.64 & 0.12 & 42.27 \\
\hline Cat- $\mathrm{K}_{2} \mathrm{CO}_{3}$ & 75.65 & 10.36 & 5.10 & 8.89 & 36.46 & 1.64 & 0.09 & 44.09 \\
\hline
\end{tabular}

${ }^{\mathrm{a}} \mathrm{HHV}$ calculated by using Channiwala and Parikh correlation [9]. ${ }^{\mathrm{b}}$ Oxygen calculated by $(\mathrm{O}=100-\mathrm{C}-\mathrm{H}-\mathrm{N})$.

\subsection{Effect of Aqueous Phase Recycling on HTL Product Yield}

In the second phase, the condition (350-None) was selected as the reference or baseline run (C0). The series of a total eight ( $\mathrm{C} 1$ to $\mathrm{C} 8)$ experiments with the recycling of aqueous phase were performed. Among them, five experiments were performed in duplicates, and the rest, $\mathrm{C} 6, \mathrm{C} 7, \mathrm{C} 8$, were carried out only once due to the smaller amount of aqueous phase that was recovered from previous runs.

Figure 4 demonstrates that bio-crude yield increased from 25 to $38 \%$ at C5, and stabilized up to $\sim 36 \%$ at C 8 . The increase in the yield is due to the saturation of WSO, especially from the $\mathrm{N}$-containing organic compounds present in the aqueous phase, which is discussed later in detail in Section 3.7. At cycles C4 and C5, it is observed that the WSO has reached the maximum level of saturation corresponding to their highest TOC values $(\sim 28 \mathrm{~g} / \mathrm{L})$, which resist the further increase in bio-crude yield. However, due to lack of aqueous phase in runs $\mathrm{C} 6-\mathrm{C} 8$, these were only carried out as single experiments, which make it impossible to evaluate these runs in detail, except to consider that yield and energy recovery seem to be stabilized for higher recycles. Almost $50 \%$ of the bio-crude yield was 
increased after eight recycles. The solid yield was inversely correlated with bio-crude yield in the range of 16 to $20 \%$ in all runs.

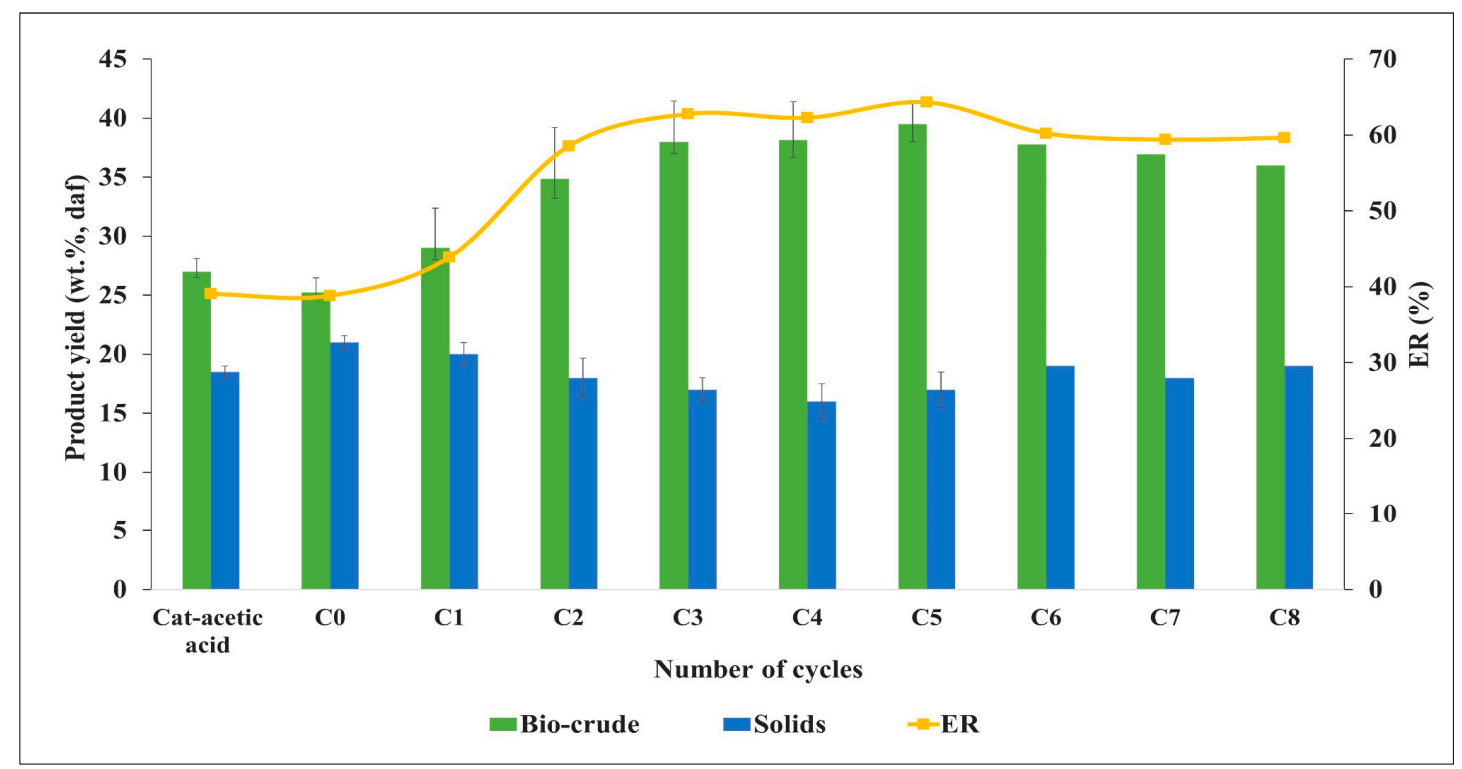

Figure 4. Effect of aqueous phase recycling on product yield.

\subsection{Influence of Acetic Acid on Bio-Crude Yield and Quality}

In earlier studies, it was noticed that acetic acid is one of the influential compounds for improving the bio-crude yield [25,37]. Therefore, to investigate the catalytic effect, $2.5 \%$ of the total slurry or $(0.56$ $\mathrm{M})$ acetic acid was used. The addition of acetic acid resulted in a negligible (1.5\%) increase in bio-crude yield. Ross et al. [38] mentioned that the decomposition of small chain organic acids forms in-situ hydrogen and carbon monoxide, the in-situ hydrogen would further act as a proton donor to improve bio-crude yield.

To further explore this mystery, the concentration of acetic acid in all aqueous phases was determined by HPLC. The standard calibration was drawn with $\left(R^{2}=0.999\right)$ to determine the concentration of acetic acid, as given in Figure S2 (Supplementary Materials).

The plots of bio-crude yield versus the concentration of acetic acid are shown in Figure 5. The maximum concentration of acetic acid $(27 \mathrm{~g} / \mathrm{L})$ was detected when acetic acid was used as a catalyst itself. However, the bio-crude yield was almost the same $(26.85 \%)$ as the baseline experiment. This observation confirms that acetic acid is not the only contributor to the bio-crude yield, but the overall recycling effect of WSO is responsible for the improvement of yield. This is because, during recycling experiments, the WSO undergo different chemical reactions such as repolymerization and cyclization, which lead to the formation of heavier fragments and become part of the bio-crude. This can also be interpreted by the higher nitrogen content in the bio-crude with successive recycles. The overall concentration of acetic acid increased with the recycling of the aqueous phase ( 2.4 to $7.1 \mathrm{~g} / \mathrm{L})$. Some variation in acetic acid concentration might be due to the variable dilution ratio, arising due to the experimental procedure and small sample amounts. 


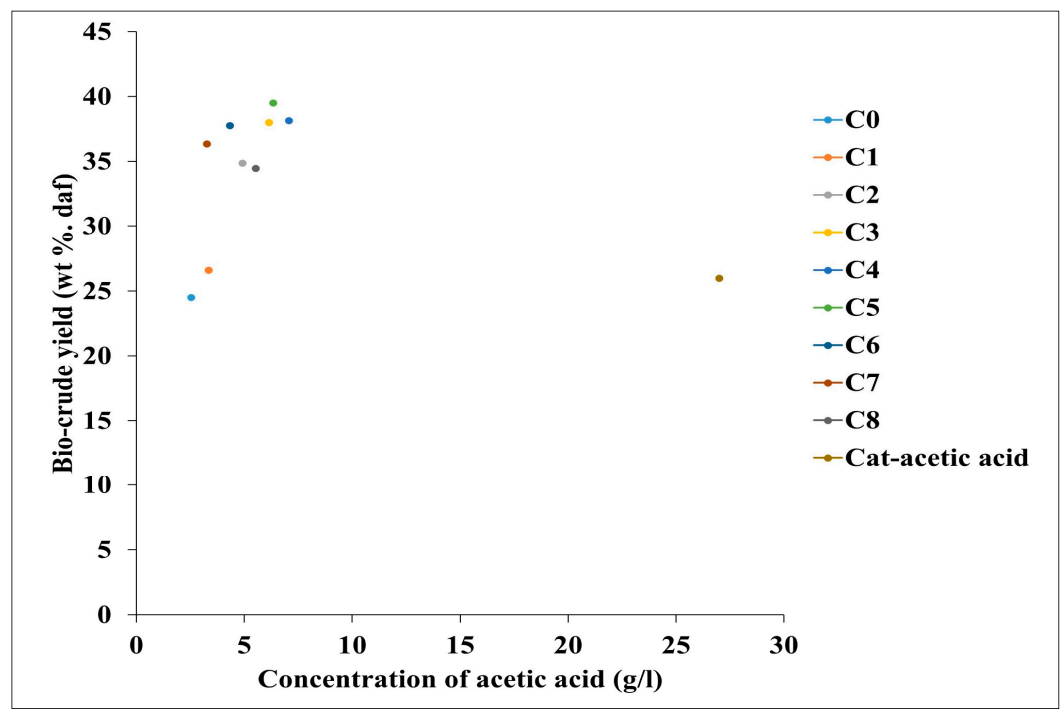

Figure 5. Effect of concentration of acetic acid on bio-crude yield.

In the recent past, Ramos-Tercero et al. experienced a mere $0.62 \%$ increase in bio-crude yield on the action of $(0.1 \mathrm{M})$ acetic acid from microalgae [27]. This is quite consistent in our case, where we used five times more concentration and obtained a $1.5 \%$ increase in yield. The variation in bio-crude yield may be due to the different chemical composition of the feedstock. In addition, the GCMS of the aqueous phase was carried out for the qualitative analysis of the organic compounds, which is in Section 3.7.

Table 5 shows the elemental composition of bio-crude. The overall carbon content in all bio-crudes was $70-74 \%$, the hydrogen was also varied by the marginal difference in the range of 9 to $10.50 \%$. Interestingly, an increasing trend of nitrogen ( 4.3 to $7.10 \%$ ) was found, especially due to the accumulation of N-containing compounds. The overall HHVs were detected in the range of 33 to $35 \mathrm{MJ} / \mathrm{kg}$, and $59 \%$ of the ER was enhanced after eight recycles. The Cat-acetic acid bio-crude contained higher oxygen content, which refers to the conversion of aqueous phase fractions to the bio-crude in the form of acids, alcohols, and other oxygenates.

Table 5. Elemental Composition, $\mathrm{O} / \mathrm{C}$ and H/C Ratios, and Energy Recovery along with consecutive recycling of the aqueous phase.

\begin{tabular}{|c|c|c|c|c|c|c|c|c|}
\hline \multirow[t]{2}{*}{ Samples } & \multicolumn{4}{|c|}{ Elemental Analysis (wt. \%) } & \multirow[t]{2}{*}{$\mathrm{HHV}(\mathrm{MJ} / \mathrm{kg})^{a}$} & \multirow[t]{2}{*}{$\mathrm{H} / \mathrm{C}$} & \multirow[t]{2}{*}{$\mathrm{O} / \mathrm{C}$} & \multirow[t]{2}{*}{ ER $(\%)$} \\
\hline & $\mathrm{C}$ & $\mathrm{H}$ & $\mathrm{N}$ & $\mathrm{O}^{\mathrm{b}}$ & & & & \\
\hline $\mathrm{CO}$ & 73.85 & 10.04 & 4.67 & 11.44 & 35.22 & 1.63 & 0.12 & 38.83 \\
\hline $\mathrm{C} 1$ & 73.89 & 9.89 & 5.10 & 11.12 & 35.09 & 1.61 & 0.11 & 43.90 \\
\hline $\mathrm{C} 2$ & 74.56 & 10.12 & 5.50 & 9.82 & 35.71 & 1.63 & 0.10 & 58.54 \\
\hline $\mathrm{C} 3$ & 73.65 & 9.96 & 5.75 & 10.64 & 35.13 & 1.62 & 0.11 & 62.76 \\
\hline $\mathrm{C} 4$ & 73.28 & 9.72 & 6.25 & 10.75 & 34.71 & 1.59 & 0.11 & 62.26 \\
\hline C5 & 72.65 & 9.85 & 6.80 & 10.70 & 34.62 & 1.63 & 0.11 & 64.30 \\
\hline C6 & 72.84 & 9.15 & 7.27 & 10.74 & 33.91 & 1.51 & 0.11 & 60.22 \\
\hline $\mathrm{C} 7$ & 72.09 & 10.14 & 6.95 & 10.82 & 34.76 & 1.69 & 0.11 & 59.39 \\
\hline $\mathrm{C} 8$ & 71.27 & 9.66 & 7.10 & 11.97 & 33.82 & 1.63 & 0.13 & 59.63 \\
\hline Cat-acetic acid & 72.51 & 9.89 & 5.1 & 12.52 & 34.48 & 1.64 & 0.13 & 39.75 \\
\hline
\end{tabular}

\footnotetext{
${ }^{a}$ HHV calculated by Channiwala and Parikh correlation [9]. ${ }^{b}$ Oxygen calculated by difference $(\mathrm{O}=100-\mathrm{C}-\mathrm{H}-\mathrm{N})$.
}

The $\mathrm{H} / \mathrm{C}$ (1.51 to 1.69$)$, and $\mathrm{O} / \mathrm{C}(0.10$ to 0.13$)$ ratios were also calculated. The lower $\mathrm{O} / \mathrm{C}$ ratio of the bio-crude indicates the conversion of SS via dehydration and decarboxylation reactions, as illustrated in Figure 6. High operating conditions accelerate the rate of dehydration and decarboxylation reactions, which take away the oxygen in the form of water and carbon dioxide. Lower $\mathrm{O} / \mathrm{C}$ ratio improves the 
stability of the bio-crude, which could reduce the hydrogen demand for the upgrading of the bio-crude. Among all bio-crudes, the higher degree of deoxygenation was calculated at bio-crude from run C2 (72.5\%) with maximum calorific value $35.71 \mathrm{MJ} / \mathrm{kg}$.

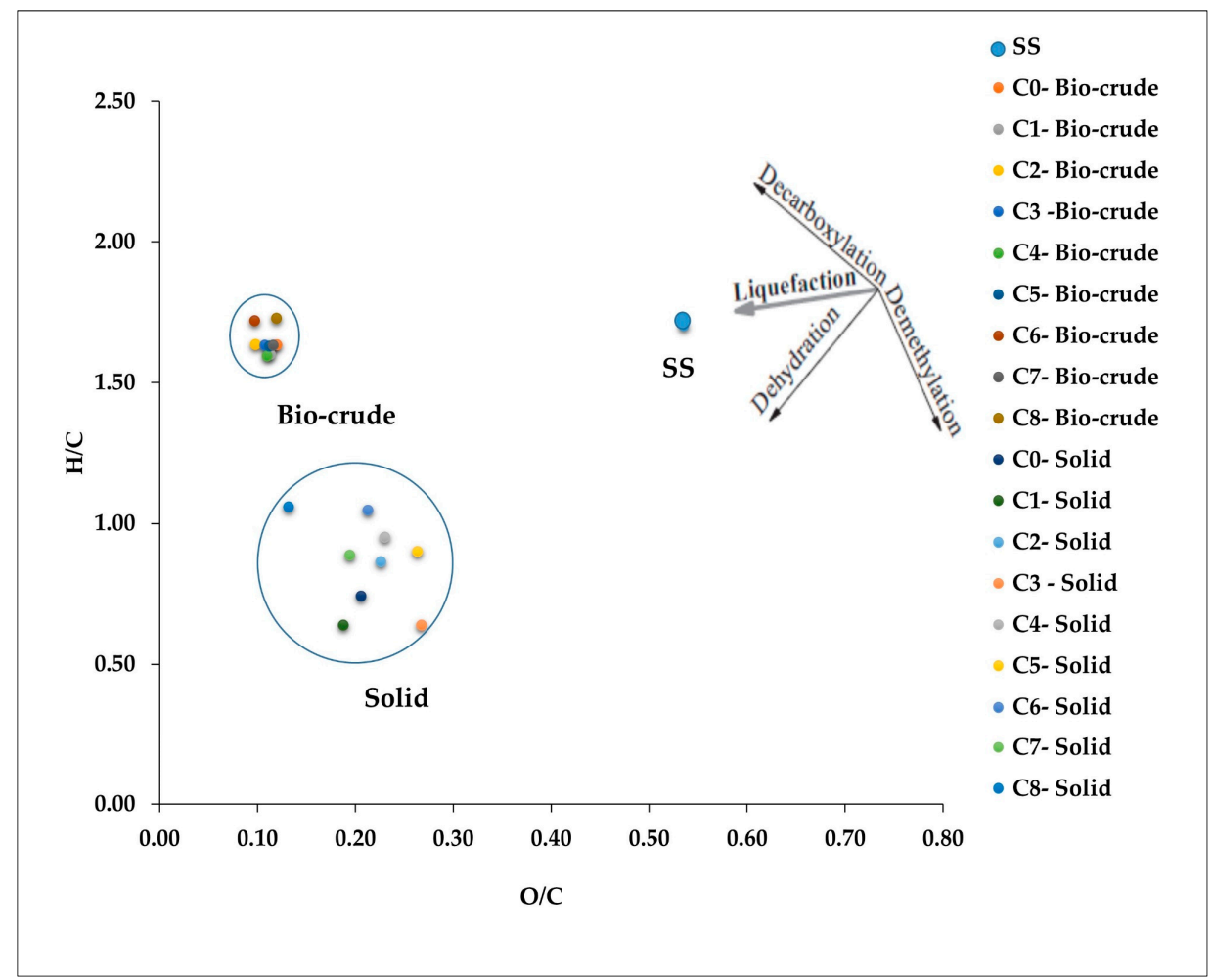

Figure 6. Van Krevelan diagram shows the pathways of liquefaction products.

\subsection{Thermal Behavior of Bio-Crude}

To assess the thermal behavior of the bio-crude, the TGA analysis was conducted. It was noticed that from all the bio-crudes except Cat- $\mathrm{K}_{2} \mathrm{CO}_{3}$, almost $65 \%$ of the mass was volatilized at temperatures $\leq 350{ }^{\circ} \mathrm{C}$ Figure 7a. To elaborate further, the Differential Thermogravimetric (DTG) curves are presented in Figure $7 \mathrm{~b}$, which confirm the volatility analysis as the highest rate of weight loss can be seen at the temperatures around $200-300{ }^{\circ} \mathrm{C}$.

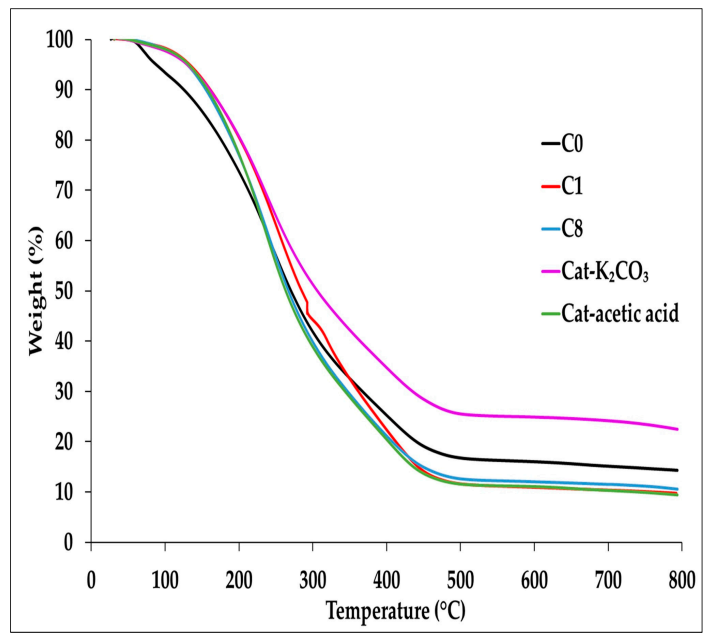

(a)

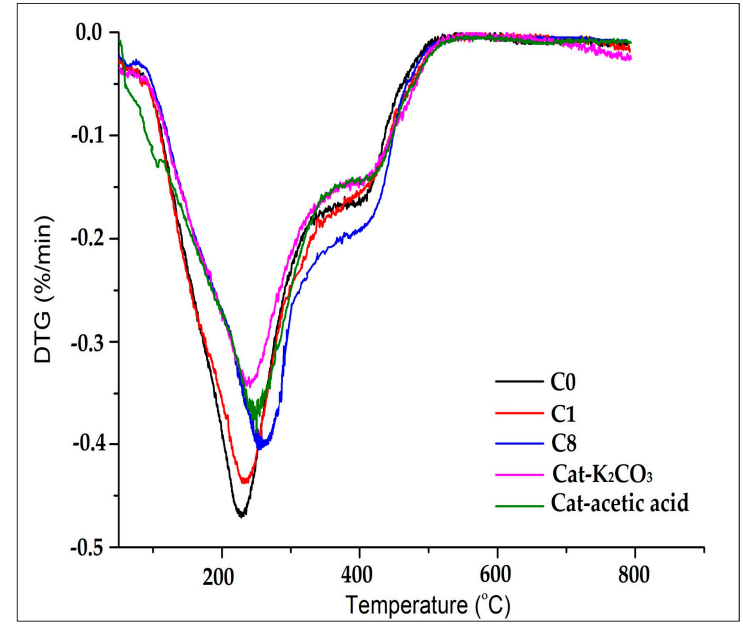

(b)

Figure 7. (a) Volatility curves of bio-crudes, and (b) DTG curves of bio-crudes. 
Figure 7a also shows that aqueous phase recycling considerably changed the thermal behavior of the bio-crudes as $\mathrm{C} 1$ and $\mathrm{C} 8$ contained a higher mass of heavier fractions with respect to $\mathrm{C} 0$ in the range of 100 to $200^{\circ} \mathrm{C}$. It clearly designates the accumulation of high boiling point components produced through the action of recycling. Cat-acetic acid bio-crude showed the same trend as other bio-crudes from recycling. At extreme temperatures $\left(800^{\circ} \mathrm{C}\right)$, almost $10-15 \%$ of heavy residue was detected from all the bio-crudes except Cat- $\mathrm{K}_{2} \mathrm{CO}_{3}$, which carried around $25 \%$ of the non-volatilized fragments.

\subsection{Compound Composition of Bio-Crude}

GCMS analysis was performed for the identification of organic compounds in the bio-crude at 300 ${ }^{\circ} \mathrm{C}$. The GCMS has only described the partial information of the TGA, as almost $60 \%$ of the bio-crude was analyzed. The chromatogram detected a total of 200 compound peaks from which 35 to 40 peaks covered more than $50 \%$ of the area. However, the smaller peaks with lower probabilities caused great difficulty for the identification of the particular functional group of the compound. Irrespectively, the heteroatoms, such as nitrogen and oxygen, were quite distinctly visible from these chromatograms, and it is worth to separate them from hydrocarbons. In this context, the organic compounds are classified as $\mathrm{N}$-containing compounds (N\&O heterocyclic compounds and amides), Oxygenated compounds (ketones, alcohols, acids, and esters, etc.), and Hydrocarbons.

In Figure $8 \mathrm{a}$, the bio-crude $\mathrm{C} 0$ contained around $24 \%$ of the $\mathrm{N}$-containing compounds, which were exceeded up to $53 \%$ and $48 \%$ in the $\mathrm{C} 5$ and $\mathrm{C} 8$, respectively. These $\mathrm{N}$-containing compounds were extensively increased due to two possible reasons: (1) high concentration of proteins in the feedstock and (2) the addition of surplus nitrogen from the aqueous phase during recycling.

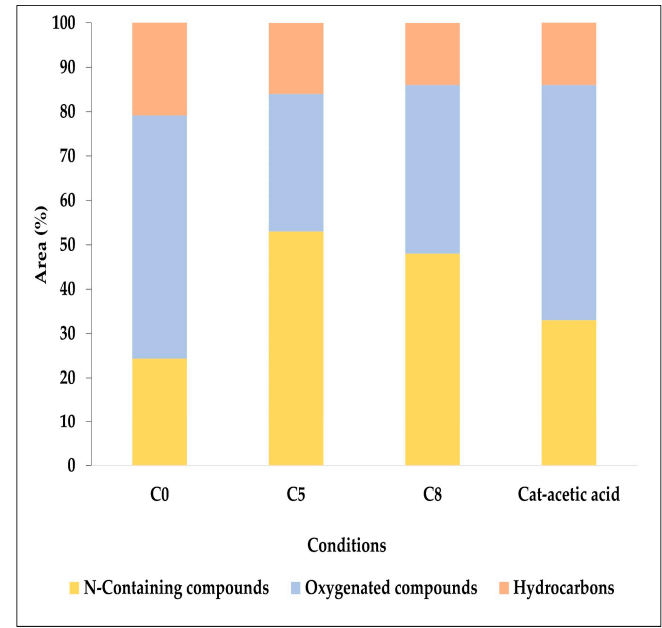

(a)

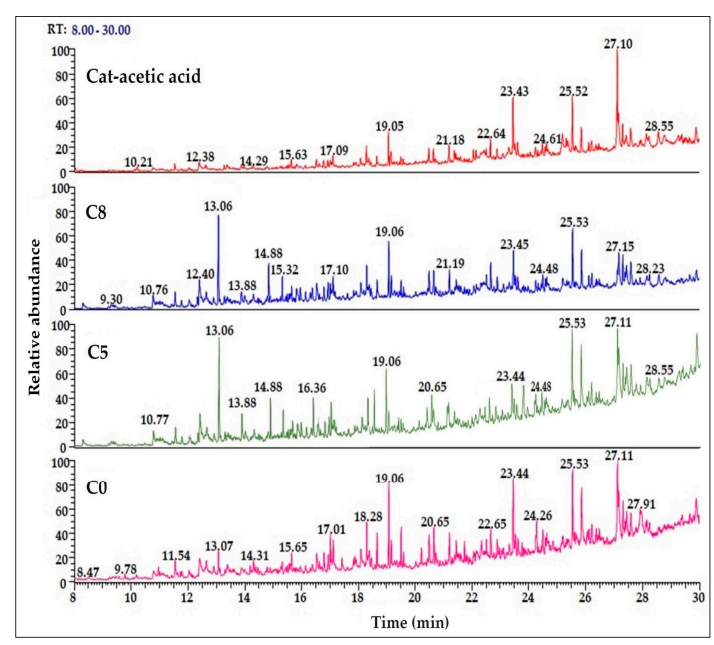

(b)

Figure 8. (a) Effect of aqueous phase recycling on the composition of bio-crudes, and (b) chromatograms of bio-crudes.

For further verification, it can be seen from the chromatograms in Figure $8 \mathrm{~b}$ that the peak area of N\&O heterocyclic compound [RT: $13.06 \mathrm{~min}$, 4-Piperidinone-2,2,6,6-tetramethyl] was increased with consecutive recycling due to higher degree of Maillard reaction between the polysaccharides (carbohydrates) and amino acids (proteins) [39]. Interestingly the amides remained in the same range 6 to $9 \%$. These amides originated purely from the acylation reaction of fatty acids with amines [40].

Here, Figure $8 \mathrm{~b}$ also represents the formation of new N-containing compounds in $\mathrm{C} 5$, such as: [RT: 14.88 min, N-Nitro-N-N-pentamethyleneguanidine] and [RT: 16.36, 2-Propen-1-amine, N, N-bis (1-methyl-ethyl)]. No larger peaks of N\&O heterocyclic compounds were detected in Cat-acetic acid bio-crude; on the other hand, higher amides, particularly [RT: $27.11 \mathrm{~min}, 9-$ 9ctadecenamide-Z] were observed. As a result, Cat-acetic acid bio-crude contained only $32 \%$ of the $\mathrm{N}$-containing compounds with the majority of oxygenated compounds. In all bio-crudes, hydrocarbons were accounted for 
10 to $20 \%$. According to Abdelmoez et al. [41], the acidic environment facilitates the decomposition of protein. From this statement, it can be hypothesized that acetic acid might change the reaction pathway of the amino-acids to amides by the reaction with fatty acids, instead of interacting with polysaccharides to form N-heterocyclic compounds. Earlier, Biller et al. also reported higher amides while using formic acid as a catalyst with different types of microalgae [42]. Straight long-chain compounds like hexadecane, originating via decarboxylation reactions from saturated fatty acids [14]. The few aromatic compounds, such as p-cresol and phenol, were observed in smaller magnitudes, which were conceivably formed by the dehydration and cyclization reactions of cellulose [43], as given in Table 6. From these results, it can be deduced that recycling of aqueous phase is beneficial for the bio-crude yield, but at the same time, it increases the heteroatoms, especially the nitrogen content, which requires hydro-treatment to meet the standards of drop-in fuels.

Table 6. The major organic compounds detected in bio-crude at different conditions.

\begin{tabular}{ccccccc}
\hline S.No. & RT & Compounds & \multicolumn{4}{c}{ Peak Area (\%) } \\
\hline & & & C0 & C5 & C8 & Cat-acetic acid \\
1 & 2.42 & Butane, 2,3-dimethyl- & 5.42 & 4.38 & 2.63 & 2.91 \\
2 & 10.79 & Phenol & 0.23 & 0.25 & 2.12 & 0.8 \\
3 & 12.41 & p-Cresol & 2.54 & ND & 3.93 & 2.06 \\
4 & 13.06 & 4-Piperidinone, 2,2,6,6-tetramethyl- & 4.95 & 20.42 & 18.56 & ND \\
5 & 19.06 & Hexadecane & 4.48 & 2.21 & 4.15 & 3.31 \\
6 & 23.44 & n-Hexadecanoic acid & 5.32 & 1.63 & 3.9 & 7.02 \\
7 & 25.53 & Dodecanamide & 5.12 & 4.19 & 6.45 & 7.95 \\
8 & 25.85 & N-Methyldodecanamide & 5.27 & 3.22 & 3.7 & 3.35 \\
9 & 27.11 & 9-Octadecenamide, (Z)- & 9.71 & 6.39 & 5.66 & 17.3 \\
\hline
\end{tabular}

ND: Not detected.

\subsection{Carbon Recovery (CR)}

The $\mathrm{CR}$ in the products was determined by the formula as the ratio of carbon in the product to the carbon in the SS, multiplied by the yield of the product. For the aqueous phase, the CR was calculated by the TOC values [assuming, water in = water out $(\mathrm{mL})]$. For the recycling experiments, the extra carbon from aqueous phase recycling was also taken as the input carbon along with the carbon in the feedstock, as given in Equation (5). Here, the aqueous phase carried 10 to $19 \%$ of the carbon, out of which almost $45 \%$ of the recovered carbon from each cycle was recirculated back with the feed to the HTL.

Figure 9 represents that carbon was mainly distributed in the bio-crude and solid phase. With consecutive recycling, the $\mathrm{CR}$ in the bio-crude was increased from 34 to 46 . This increase is strongly associated with the substantial rise in bio-crude yield, although the comparable values for carbon and hydrogen contents were detected by the elemental analyzer. The CR in the solids was almost consistent in the range of 22 to $29 \%$. Slightly lower carbon in the gases was estimated with recycling, which may be due to condensation of light fractions to aqueous phase or bio-crude.

\subsection{Characterization of the Aqueous Phase}

The earlier sections highlighted that the recycling of the WSO from aqueous phase has a huge role in increasing bio-crude yield. Thus, the organic composition of the aqueous phase was analyzed by GCMS. Therefore, two separate runs were carried out to produce a sufficient amount of the aqueous phase. The aqueous phase produced from the second recycle $\mathrm{C} 2$ was selected for the characterization. The compounds listed in Table 7, covered $60 \%$ of the total $70 \%$ of the area. For further validation, the chromatogram is also presented in Figure S3 (Supplementary material). 


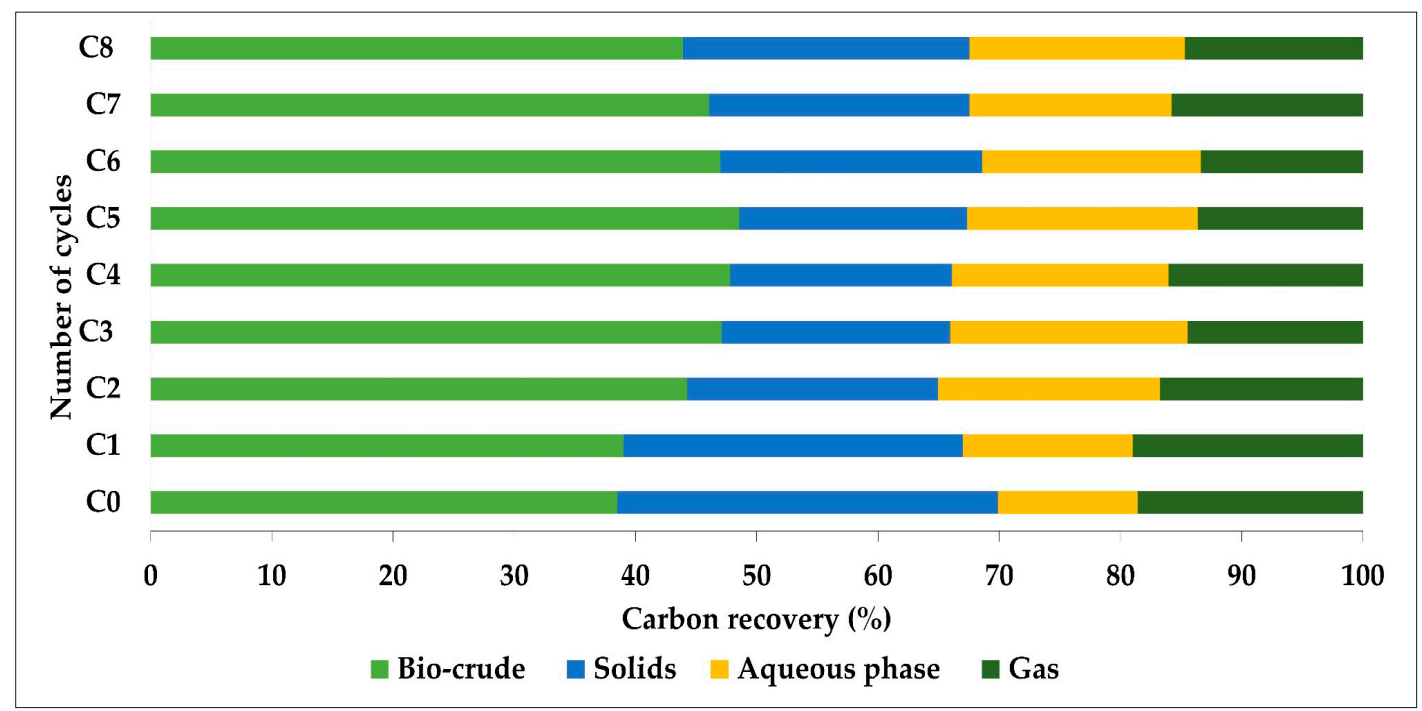

Figure 9. Carbon recovery in HTL products via aqueous phase recycling.

Table 7. Compound composition of aqueous phase produced after the second recycle C2.

\begin{tabular}{|c|c|c|c|c|}
\hline S.No. & RT & Compounds & Formula & Peak Area $(\%)$ \\
\hline 1 & 3.44 & Acetic acid & $\mathrm{CH}_{3} \mathrm{COOH}$ & 5.36 \\
\hline 2 & 7.54 & Acetamide & $\mathrm{C}_{2} \mathrm{H}_{5} \mathrm{NO}$ & 3.09 \\
\hline 3 & 9.14 & Acetamide, N-ethyl- & $\mathrm{C}_{4} \mathrm{H}_{9} \mathrm{NO}$ & 3.03 \\
\hline 4 & 11.44 & Pentanoic acid, 4-methyl- & $\mathrm{C}_{6} \mathrm{H}_{12} \mathrm{O}_{2}$ & 3.04 \\
\hline 5 & 12.74 & 2,5-Pyrrolidinedione, 1-methyl- & $\mathrm{C}_{5} \mathrm{H}_{7} \mathrm{NO}_{2}$ & 13.54 \\
\hline 6 & 13.18 & 3-Aminopyridine & $\mathrm{C} 5 \mathrm{H}_{6} \mathrm{~N}_{2}$ & 5.11 \\
\hline 7 & 13.44 & 2,5-Pyrrolidinedione, 1-ethyl- & $\mathrm{C}_{6} \mathrm{H}_{9} \mathrm{NO}_{2}$ & 3.51 \\
\hline 8 & 14.36 & Cyclooctanone, oxime & $\mathrm{C}_{9} \mathrm{H}_{17} \mathrm{NO}$ & 6.18 \\
\hline 9 & 14.51 & 2-Piperidinone & $\mathrm{C}_{4} \mathrm{H}_{7} \mathrm{NO}$ & 7.48 \\
\hline 10 & 22.54 & 4(1H)-Pyridinone,tetrahydro-2,5-dimethyl-1-(1-methylethyl)- & $\mathrm{C}_{11} \mathrm{H}_{18} \mathrm{~N}_{2} \mathrm{O}_{2}$ & 3.70 \\
\hline 11 & 23.52 & Pyrrolo[1,2-a]pyrazine-1,4-dione, hexahydro-3-(2-methylpropyl)- & $\mathrm{C}_{11} \mathrm{H}_{18} \mathrm{~N}_{2} \mathrm{O}_{2}$ & 7.19 \\
\hline \multicolumn{4}{|c|}{ Total area detected } & $70.85 \%$ \\
\hline
\end{tabular}

The aqueous phase contained the majority of the N-containing compounds, such as [RT: 12.74, 2,5-Pyrrolidinedione, 1-methyl-], which resulted from the Maillard reaction. Some light short-chain acids, such as Acetic acid, and Pentanoic acid, 4-methyl, were also detected, these acids may have originated from the hydrolysis and dehydration of cellulose. The small chain water-soluble acids serve as a precursor for bio-crude and become part of the aqueous phase [20,25]. In another study, Madsen et al. quantitatively characterized the aqueous phases from the modal biomass components and found a higher concentration of acetic acid $(2600 \mathrm{mg} / \mathrm{L})$ in pure proteins due to deamination of the amino acid (glycine) as compared to carbohydrates (1700 mg/L) [44]. Therefore, it is still challenging to predict the exact pathway for the formation of acetic acid. Acetamide was formed by the reaction of acetic acid and ammonia (liberated from the deamination of amino acids) [16]. In short, the compound composition of the aqueous phase replicates the overall biochemical composition of the SS.

With successive recycling rounds, the TOC and TN values were both increased by 2.6 and 2 times, respectively. The TOC value rose from 12.8 to $27 \mathrm{~g} / \mathrm{L}$ at C5, which reflects that WSO has reached its equilibrium/steady-state, and no more organics are further dissolved in the aqueous phase. Slight lower TOCs at runs $\mathrm{C} 6-\mathrm{C} 8$ can be ascribed to higher dilution ratios. The same trend was observed in $\mathrm{TN}$, as shown in Figure 10. 


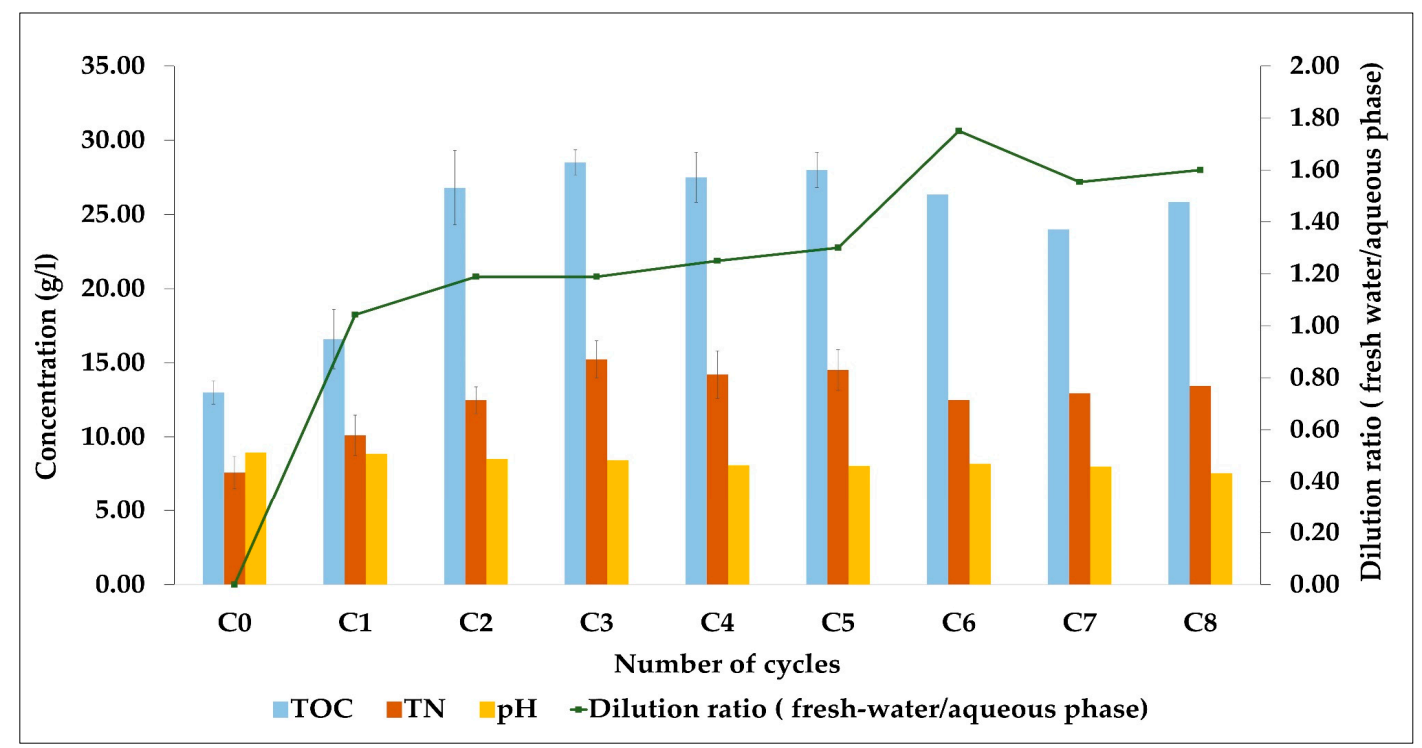

Figure 10. TOC, TN, and $\mathrm{pH}$ of aqueous phase.

The literature related to water recirculation studies shows the continuous increase in TOCs with successive recycling. Biller et al. observed the sharp rise in TOC from 25 to $90 \mathrm{~g} / \mathrm{L}$ after nine recycles [28]. Similarly, Pedersen et al. has also noticed the high increase in TOC from 54 to $136.2 \mathrm{~g} / \mathrm{L}$ after three recycles on continuous pilot-scale plant [26]. In our case, the TOC level gradually rose from 12.8 to $26-29 \mathrm{~g} / \mathrm{L}$ after eight rounds. This is quite understandable because here, we have diluted the aqueous phase, as water dilution slowly increases the TOC level unless it reaches the steady state. Secondly, the continuous plant scale results are difficult to compare with laboratory-oriented batch scale experiments. The overall $\mathrm{pH}$ values were found in the range of 8.80 to 7.56 , the slight decrease in $\mathrm{pH}$ was noticed, which is correlated with an increased concentration of acetic acid with continuous recycling. Nevertheless, all the $\mathrm{pH}$ values displayed in the alkaline range. The aqueous phases from catalytic runs Cat-acidic acid and Cat- $\mathrm{K}_{2} \mathrm{CO}_{3}$ had pH values 5.86 and 8.96, respectively, owing to their high concentration of $\mathrm{H}^{+}$and $\mathrm{CO}^{3-}$ ions.

The weight of the inorganics in the aqueous phase was also quantified. The $4 \mathrm{~mL}$ sample was placed in the furnace at $600{ }^{\circ} \mathrm{C}$ for $4 \mathrm{~h}$ at $5{ }^{\circ} \mathrm{C} / \mathrm{min}$ ramp. The difference was noted down, and the remaining material was counted as the weight of the inorganics. It was found that the inorganic content in the aqueous phase increased from 0.53 to $0.79 \%$ for $\mathrm{C} 0$ and $\mathrm{C} 2$, respectively. This infers that during the recycling, not only organic matter is transferred to the aqueous phase, but some fractions of inorganics are also contributed in the aqueous phase. This finding is further supported by ICP-AES results in Figure 11; where we could see more amount of potassium and sodium in the aqueous phase at recycle $\mathrm{C} 5$ as compared to $\mathrm{C} 0$.

\subsection{Distribution of Inorganic Elements}

To assess the effect of aqueous phase recycling on the distribution of inorganics in the products, a total of nine inorganic elements were detected through ICP-AES. The (weight \%) of each element was calculated by multiplying the concentration of each inorganic element to the weight of each product. For a single inorganic element, the distribution was normalized with respect to the total amount of inorganic element obtained in all phases, as bio-crude, solids, and aqueous phase. The level of quantification was $(0.01 \mathrm{mg} / \mathrm{kg})$ for all elements. 


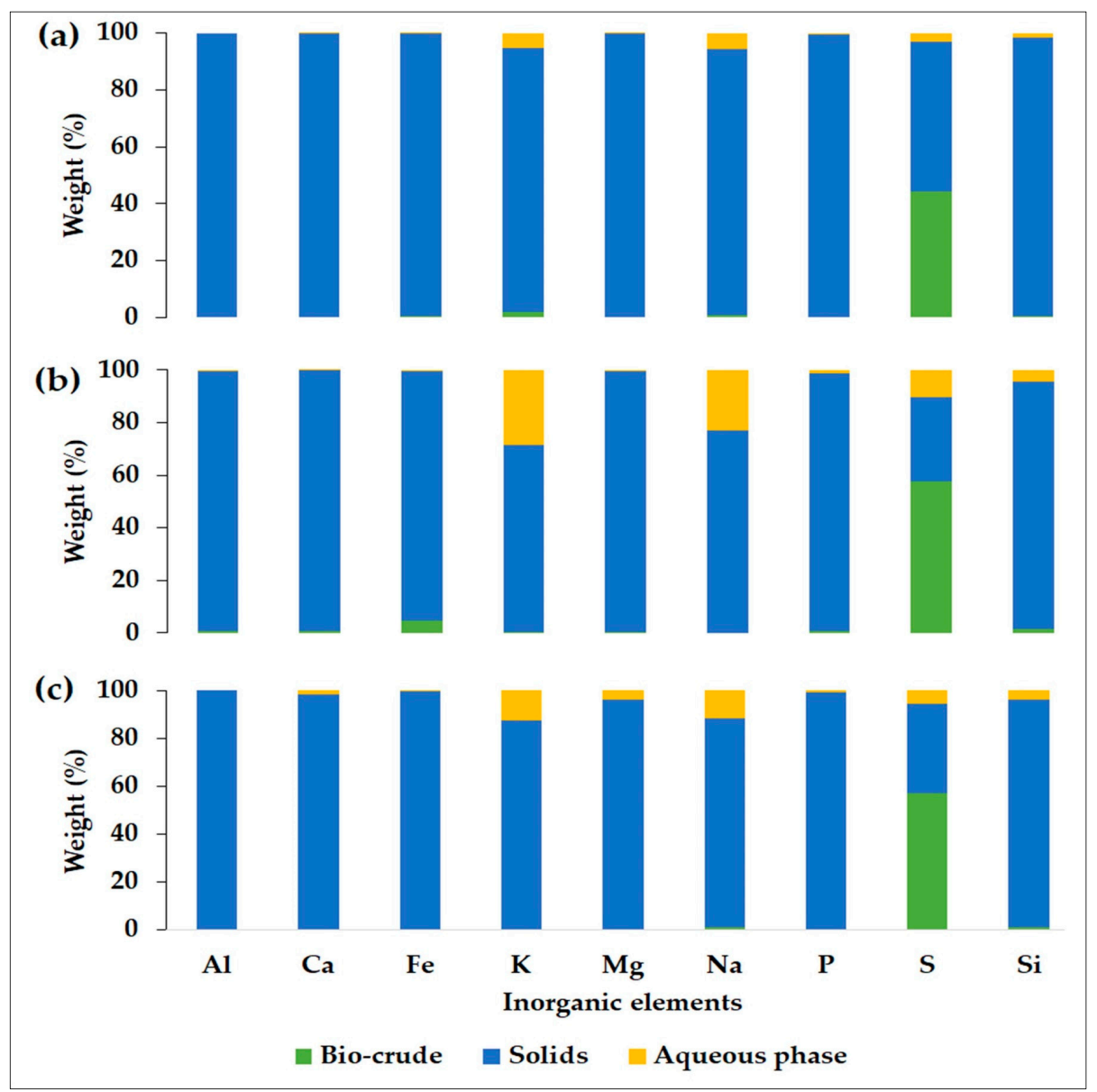

Figure 11. Distribution of inorganic elements at (a) C0, (b) C5, and (c) Cat-acetic acid.

Figure 11a shows the distribution in the baseline run (C0); almost $99 \%$ of the mass of $\mathrm{Al}, \mathrm{Ca}, \mathrm{Fe}$, and $\mathrm{Mg}$ was migrated to the solid phase. The potassium and sodium were transferred 5 to $6 \%$ to the aqueous phase, whereas $40 \%$ of the sulfur was observed to the bio-crude. This may be due to the cleavage of sulfur-containing organic compounds in the feedstock.

Huang et al. reported in his review article related to liquefaction of SS that irrespective of temperature conditions, the majority of inorganic elements concentrated into the solids phase [45]. From recycle $\mathrm{C} 5$, the solid phase contained the majority of the inorganic elements, except potassium and sodium, which went around $20 \%$ and $16 \%$ in the aqueous phase, respectively. This is quite logical because continuous recycling of the aqueous phase builds up higher amount of inorganic elements that disintegrated from the original feedstock, as illustrated in Figure 11b. Earlier, Pederson et al. already confirmed the accumulation of ash from 5 to $12 \%$ in the aqueous phase with recycling rounds from co-liquefaction of wood and glycerol [26]. However, sulfur was distributed in all three phases. This sulfur could assist in the hydrotreating process for the catalytic upgrading of bio-crude, especially for sulfided CoMo and NiMo catalysts [46].

Figure 11c shows more or less the same distribution in Cat-acetic acid as the baseline experiment. Again, a higher amount of sulfur was observed in bio-crude. This may be due to the catalytic action of acetic acid on the degradation of polysaccharides containing sulfur in the ring structure. In the recent past, Conti at al. has already investigated the distribution of inorganics from willow in supercritical water and reported a significant amount of alkali metals in the aqueous phase and $50 \%$ of the sulfur in the bio-crude [33].

In a broader context, one interesting outcome was found; the solid phase contained the majority of the phosphorus in all three conditions, which means that the migration of phosphorus was not 
affected by the recirculation of aqueous phase or catalytic action of acetic acid. This phosphorus has existed in the form of phosphates with its other allied elements $\mathrm{Al}, \mathrm{Ca}, \mathrm{Na}$, and $\mathrm{K}$, which were also present in higher concentrations in the feedstock. This significant amount of phosphorus could unlock another gateway for the utilization of the solid phase as a fertilizer for the cultivation of biomass.

\section{Conclusions}

In this article, the valorization of aqueous phase generated from HTL of SS has been discussed in detail. Initially, SS was hydrothermally liquefied with and without catalyst $\left(\mathrm{K}_{2} \mathrm{CO}_{3}\right)$. The results revealed that the alkali catalyst is proved beneficial for high carbohydrate-containing SS. Acetic acid was produced as a significant water-soluble product, and employed as a catalyst $(0.56 \mathrm{M})$ to baseline conditions, which resulted only $\sim 1.5 \%$ increase in bio-crude yield with slightly lower HHV (34.48 $\mathrm{MJ} / \mathrm{kg}$ ). In the second phase, the recycling effect of the aqueous phase was investigated, which resulted in a $50 \%$ increase in bio-crude yield and energy recovery. However, aqueous phase recycling also increased the nitrogen content in bio-crude from 4.3 to $7.1 \%$. Furthermore, HPLC analysis revealed that the overall recycling effect of the WSO is responsible for the improvement of bio-crude yield.

In the whole scenario, aqueous phase recycling increases the bio-crude energy recovery, but at the same time, it imparts more heteroatoms in the bio-crude, which requires more energy and cost for hydro-treatment. Therefore, reduction of the heteroatoms should be a target of further recycling studies in the future, combined with techno-economic studies to estimate the pros and cons of post-HTL hydro-treatment versus nitrogen-reduction measures.

Supplementary Materials: The following are available online at http://www.mdpi.com/1996-1073/13/2/493/s1, Figure S1. Thermogravimetric curves of SS (a) Volatility curves (b) DTG curves. Figure S2. Calibration curve and concentration of acetic acid in the aqueous phase at different recycles. Figure S3. Chromatogram of aqueous phase produced from second recycle $\mathrm{C} 2$.

Author Contributions: A.A.S. (experiments, analysis, result interpretation, and main contribution in overall writing and designing of the manuscript). S.S.T. (experiments, methodology, and supervision). T.H.S. (experiments, analysis of the products, and results interpretation). R.S.N. (HPLC analysis). A.H.N. (ICP-AES). T.H.P. (result interpretation and review), and L.A.R. (Main supervision, and overall conceptualization of this study). All authors have read and agreed to the published version of the manuscript.

Funding: This research work was funded by the Higher Education Commission (HEC) of Pakistan under the program of "Strengthening of Dawood University of Engineering and Technology, Karachi", and NextGenRoadFuels (NGRF- Project No. 888101), under the Grant No. 818413.

Conflicts of Interest: The authors declare no conflict of interest. The funding agency had no role in the design of the study, writing manuscript, and in the decision to publish results.

\section{References}

1. Kumar, M.; Olajire Oyedun, A.; Kumar, A. A review on the current status of various hydrothermal technologies on biomass feedstock. Renew. Sustain. Energy Rev. 2018, 81, 1742-1770. [CrossRef]

2. Akhtar, J.; Amin, N.A.S. A review on process conditions for optimum bio-oil yield in hydrothermal liquefaction of biomass. Renew. Sustain. Energy Rev. 2011, 15, 1615-1624. [CrossRef]

3. Castello, D.; Pedersen, T.H.; Rosendahl, L.A. Continuous hydrothermal liquefaction of biomass: A critical review. Energies 2018, 11, 3165. [CrossRef]

4. Fonts, I.; Gea, G.; Azuara, M.; Ábrego, J.; Arauzo, J. Sewage sludge pyrolysis for liquid production: A review. Renew. Sustain. Energy Rev. 2012, 16, 2781-2805. [CrossRef]

5. Wang, L.; Chang, Y.; Li, A. Hydrothermal carbonization for energy-efficient processing of sewage sludge: A review. Renew. Sustain. Energy Rev. 2019, 108, 423-440. [CrossRef]

6. Kelessidis, A.; Stasinakis, A.S. Comparative study of the methods used for treatment and final disposal of sewage sludge in European countries. Waste Manag. 2012, 32, 1186-1195. [CrossRef] [PubMed]

7. Manara, P.; Zabaniotou, A. Towards sewage sludge based biofuels via thermochemical conversion-A review. Renew. Sustain. Energy Rev. 2012, 16, 2566-2582. [CrossRef]

8. Huang, H.; Yuan, X.; Li, B.; Xiao, Y. Thermochemical liquefaction characteristics of sewage sludge in different organic solvents. J. Anal. Appl. Pyrolysis 2014, 109, 176-184. [CrossRef] 
9. Parikh, J.; Channiwala, S.; Ghosal, G. A correlation for calculating HHV from proximate analysis of solid fuels. Fuel 2005, 84, 487-494. [CrossRef]

10. Elliott, D.C.; Biller, P.; Ross, A.B.; Schmidt, A.J.; Jones, S.B. Hydrothermal liquefaction of biomass: Developments from batch to continuous process. Bioresour. Technol. 2015, 178, 147-156. [CrossRef]

11. Li, R.; Ma, Z.; Yang, T.; Li, B.; Wei, L.; Sun, Y. Sub-supercritical liquefaction of municipal wet sewage sludge to produce bio-oil: Effect of different organic-water mixed solvents. J. Supercrit. Fluids 2018, 138, 115-123. [CrossRef]

12. Qian, L.; Wang, S.; Savage, P.E. Hydrothermal liquefaction of sewage sludge under isothermal and fast conditions. Bioresour. Technol. 2017, 232, 27-34. [CrossRef]

13. Malins, K.; Kampars, V.; Brinks, J.; Neibolte, I.; Murnieks, R.; Kampare, R. Bio-oil from thermo-chemical hydro-liquefaction of wet sewage sludge. Bioresour. Technol. 2015, 187, 23-29. [CrossRef]

14. Liu, R.; Tian, W.; Kong, S.; Meng, Y.; Wang, H.; Zhang, J. Effects of inorganic and organic acid pretreatments on the hydrothermal liquefaction of municipal secondary sludge. Energy Convers. Manag. 2018, 174, 661-667. [CrossRef]

15. Prestigiacomo, C.; Costa, P.; Pinto, F.; Schiavo, B.; Siragusa, A.; Scialdone, O.; Galia, A. Sewage sludge as cheap alternative to microalgae as feedstock of catalytic hydrothermal liquefaction processes. J. Supercrit. Fluids 2019, 143, 251-258. [CrossRef]

16. Maddi, B.; Panisko, E.; Wietsma, T.; Lemmon, T.; Swita, M.; Albrecht, K.; Howe, D. Quantitative Characterization of Aqueous Byproducts from Hydrothermal Liquefaction of Municipal Wastes, Food Industry Wastes, and Biomass Grown on Waste. ACS Sustain. Chem. Eng. 2017, 5, 2205-2214. [CrossRef]

17. Xu, D.; Lin, G.; Liu, L.; Wan, Y.; Jing, Z.; Wang, S. Comprehensive evaluation on product characteristics of fast hydrothermal liquefaction of sewage sludge at different temperatures. Energy 2018, 159, 686-695. [CrossRef]

18. Pham, M.; Schideman, L.; Sharma, B.K.; Zhang, Y.; Chen, W.T. Effects of hydrothermal liquefaction on the fate of bioactive contaminants in manure and algal feedstocks. Bioresour. Technol. 2013, 149, 126-135. [CrossRef]

19. Valdez, P.J.; Nelson, M.C.; Wang, H.Y.; Lin, X.N.; Savage, P.E. Hydrothermal liquefaction of Nannochloropsis sp.: Systematic study of process variables and analysis of the product fractions. Biomass Bioenergy 2012, 46, 317-331. [CrossRef]

20. Hu, Y.; Feng, S.; Yuan, Z.; Xu, C.C.; Bassi, A. Investigation of aqueous phase recycling for improving bio-crude oil yield in hydrothermal liquefaction of algae. Bioresour. Technol. 2017, 239, 151-159. [CrossRef]

21. Cherad, R.; Onwudili, J.A.; Biller, P.; Williams, P.T.; Ross, A.B. Hydrogen production from the catalytic supercritical water gasification of process water generated from hydrothermal liquefaction of microalgae. Fuel 2016, 166, 24-28. [CrossRef]

22. Pedersen, T.H.; Hansen, N.H.; Pérez, O.M.; Cabezas, D.E.V.; Rosendahl, L.A. Renewable hydrocarbon fuels from hydrothermal liquefaction: A techno-economic analysis. Biofuels Bioprod. Biorefining 2018, 12, $213-223$. [CrossRef]

23. López Barreiro, D.; Bauer, M.; Hornung, U.; Posten, C.; Kruse, A.; Prins, W. Cultivation of microalgae with recovered nutrients after hydrothermal liquefaction. Algal Res. 2015, 9, 99-106. [CrossRef]

24. Tommaso, G.; Chen, W.T.; Li, P.; Schideman, L.; Zhang, Y. Chemical characterization and anaerobic biodegradability of hydrothermal liquefaction aqueous products from mixed-culture wastewater algae. Bioresour. Technol. 2015, 178, 139-146. [CrossRef]

25. Zhu, Z.; Rosendahl, L.; Toor, S.S.; Yu, D.; Chen, G. Hydrothermal liquefaction of barley straw to bio-crude oil: Effects of reaction temperature and aqueous phase recirculation. Appl. Energy 2015, 137, 183-192. [CrossRef]

26. Pedersen, T.H.; Grigoras, I.F.; Hoffmann, J.; Toor, S.S.; Daraban, I.M.; Jensen, C.U.; Iversen, S.B.; Madsen, R.B.; Glasius, M.; Arturi, K.R.; et al. Continuous hydrothermal co-liquefaction of aspen wood and glycerol with water phase recirculation. Appl. Energy 2016, 162, 1034-1041. [CrossRef]

27. Ramos-Tercero, E.A.; Bertucco, A.; Brilman, D.W.F. Process water recycle in hydrothermal liquefaction of microalgae to enhance bio-oil yield. Energy Fuels 2015, 29, 2422-2430. [CrossRef]

28. Biller, P.; Madsen, R.B.; Klemmer, M.; Becker, J.; Iversen, B.B.; Glasius, M. Effect of hydrothermal liquefaction aqueous phase recycling on bio-crude yields and composition. Bioresour. Technol. 2016, 220, 190-199. [CrossRef]

29. Déniel, M.; Haarlemmer, G.; Roubaud, A.; Weiss-Hortala, E.; Fages, J. Bio-oil Production from Food Processing Residues: Improving the Bio-oil Yield and Quality by Aqueous Phase Recycle in Hydrothermal Liquefaction of Blackcurrant (Ribes nigrum L.) Pomace. Energy Fuels 2016, 30, 4895-4904. [CrossRef] 
30. About Treatment Plants (n.d.). Available online: https://aalborgforsyning.dk/kloak/spildevandsrensning/omrenseanlaeg.aspx (accessed on 15 November 2019).

31. Leow, S.; Witter, J.R.; Vardon, D.R.; Sharma, B.K.; Guest, J.S.; Strathmann, T.J. Prediction of microalgae hydrothermal liquefaction products from feedstock biochemical composition. Green Chem. 2015, 17, 3584-3599. [CrossRef]

32. Huang, H.J.; Yuan, X.Z.; Zhu, H.N.; Li, H.; Liu, Y.; Li-Wang, X.; Ming-Zeng, G. Comparative studies of thermochemical liquefaction characteristics of microalgae, lignocellulosic biomass and sewage sludge. Energy 2013, 56, 52-60. [CrossRef]

33. Conti, F.; Toor, S.S.; Pedersen, T.H.; Nielsen, A.H.; Rosendahl, L.A. Biocrude production and nutrients recovery through hydrothermal liquefaction of wastewater irrigated willow. Biomass Bioenergy 2018, 11, 824-831. [CrossRef]

34. Helmer Pedersen, T.; Conti, F. Improving the circular economy via hydrothermal processing of high-density waste plastics. Waste Manag. 2017, 68, 24-31. [CrossRef]

35. Zhou, D.; Zhang, L.; Zhang, S.; Fu, H.; Chen, J. Hydrothermal Liquefaction of Macroalgae Enteromorpha prolifera to Bio-oil. Energy Fuels 2010, 24, 4054-4061. [CrossRef]

36. Yokoyama, Y.S.; Suzuki, A.; Murakami, M.; Ogi, T.; Koguchi, K.; Nakamura, E. Liquid fuel production from sewage sludge by catalytic conversion using sodium carbonate. Fuel 1987, 66, 1150-1155. [CrossRef]

37. Li, C.; Yang, X.; Zhang, Z.; Zhou, D.; Zhang, L.; Zhang, S.; Chen, J. Hydrothermal liquefaction of desert shrub salix psammophila to high value-added chemicals and hydrochar with recycled processing water. BioResources 2013, 8, 2981-2997. [CrossRef]

38. Ross, A.B.; Biller, P.; Kubacki, M.L.; Li, H.; Lea-Langton, A.; Jones, J.M. Hydrothermal processing of microalgae using alkali and organic acids. Fuel 2010, 89, 2234-2243. [CrossRef]

39. Shakya, R.; Whelen, J.; Adhikari, S.; Mahadevan, R.; Neupane, S. Effect of temperature and Na2CO3 catalyst on hydrothermal liquefaction of algae. Algal Res. 2015, 12, 80-90. [CrossRef]

40. Peterson, A.A.; Vogel, F.; Lachance, R.P.; Fröling, M.; Antal, M.J.; Tester, J.W. Thermochemical biofuel production in hydrothermal media: A review of sub- and supercritical water technologies. Energy Environ. Sci. 2008, 1, 32-65. [CrossRef]

41. Abdelmoez, W.; Nakahasi, T.; Yoshida, H. Amino acid transformation and decomposition in saturated subcritical water conditions. Ind. Eng. Chem. Res. 2007, 46, 5286-5294. [CrossRef]

42. Biller, P.; Ross, A.B. Potential yields and properties of oil from the hydrothermal liquefaction of microalgae with different biochemical content. Bioresour. Technol. 2011, 102, 215-225. [CrossRef]

43. Zhu, Z.; Toor, S.S.; Rosendahl, L.; Chen, G. Analysis of product distribution and characteristics in hydrothermal liquefaction of barley straw in subcritical and supercritical water. Environ. Prog. Sustain. Energy 2014, 33, 737-743. [CrossRef]

44. Madsen, R.B.; Biller, P.; Jensen, M.M.; Becker, J.; Iversen, B.B.; Glasius, M. Predicting the Chemical Composition of Aqueous Phase from Hydrothermal Liquefaction of Model Compounds and Biomasses. Energy Fuels 2016, 30, 10470-10483. [CrossRef]

45. Huang, H.J.; Yuan, X.Z. The migration and transformation behaviors of heavy metals during the hydrothermal treatment of sewage sludge. Bioresour. Technol. 2016, 200, 991-998. [CrossRef]

46. Yang, Y.; Gilbert, A.; Xu, C.C. Hydrodeoxygenation of bio-crude in supercritical hexane with sulfided CoMo and CoMoP catalysts supported on MgO: A model compound study using phenol. Appl. Catal. A Gen. 2009, 360, 242-249. [CrossRef]

(C) 2020 by the authors. Licensee MDPI, Basel, Switzerland. This article is an open access article distributed under the terms and conditions of the Creative Commons Attribution (CC BY) license (http://creativecommons.org/licenses/by/4.0/). 